\title{
CONVENTIONAL AND G-BANDING KARYOTYPE VARIATIONS OF THREE DUCK BREEDS OCCURRING IN EGYPT
}

\author{
ABDELTAWAB M. ATA, SAYED A.-M. OSMAN*, GEHAN M. ANWAR AND AHMED A. \\ ABDALLAH
}

\author{
Department of genetics, Faculty of Agriculture, Minia University, El Minia, Eg-61519, Egypt \\ *Corresponding Author: Dr. Sayed A.-M. Osman, E-mail: sayed.osman@mu.edu.eg
}

Received on: 26-8-2021

Accepted on: 24-10-2021

\begin{abstract}
In the present work, the chromosome variation and comparative analys is of conventional and G-banding karyotypes between three duck breeds (Pekin, Soudani and Baladi) occurring in Egypt were carried out. Almost all examined cells of the three studied duck breeds showed 7 macro-chromosome pairs and Z, W and 64 microchromosomes (less than 1 micron in size and so called microchromosomes). Some of karyological parameters such as chromosome length, $q$ and $p$ arm lengths, armratio, Intra chromosomal as ymmetry degree (AsD) and karyotypic asymmetry (AsK) were calculated. Results showed notable differences of the kary otype characteris tics between the three studied duck breeds. Likewise, the studies macrochromosomes showed three different categories of karyotypic formulas were obtained $(1 \mathrm{~m}+7 \mathrm{sm}+1 \mathrm{st}$ for Baladi, 3m+6s $m$ for Pekin and 9smfor Sudani) including sexchromosomes. Into AsD and AsK parameters also varied among the studied breeds. There was visible variation in the G- banding patterns and their constructed physical maps of the seven pairs of autosomes and sex chromosomes between the three studied duck breeds.
\end{abstract}

KEYWORDS: Karyotype, macrochromosomes, Duck breeds and G- Banding

\section{INTRODUCTION}

Duck is one of the most important domestic avian species in the world and considered for centuries an important part of animal production in Egypt. In 2016, the duck population (Anas spp.) throughout the world reached 1.24 billion and 1.1 billion (89 percent) were in Asia. Duck populations occurred in Egypt is about 15.650 million birds produce about 64478 tons of meat (FAO, 2019). Pekn duck breed is taxonomically belonging to species platyrhynchos, Genus: Anas, subtribe Anatina, tribe: Anatini, Family: Anatidae, suborder: Ansera, order: Anseriformes, class: Aves, while Sudani and Baladi duck breeds are belonging to species moschata, genus: Cairina, subtribe: Cairinina, tribe: Anatini (Livezey, 1997). Avian genome and karyotype are characterized by a small amount of genetic material and having the smallest genomes of all amniotes (Griffin et al., 2007) The diploid chromosome number of duck species (Anas platyrhynchos and Cairina moschata) were relatively the same in two species (Ata et al., 2017). And their hybrids suggested 34 to 62 chromosomes (Sokolowskaja, 1935). The reports of Yamashina (1941 and 1942) determined 80 in males and 79 in females and explained that the difference between the two sexes might be due to $\mathrm{W}$ chromosome loss. In fact, it has now been generally accepted that the diploid chromosome numbers in birds range from 40 to 126 , and the mode of the chromosome number in birds is
$2 n=80$ (Seo et al., 2016). Karyotype consists of ten large and medium-sized macrochromosome pairs (including $\mathrm{ZW}$ ) and 60 indistinguishable microchromosomes. Karyological observations on Anas platyrhynchos and Cairina moschata showed differences between them in chromosome No.1and $\mathrm{Z}$ chromosome. The short arm of chromosome one was longer in Anas platyrhynchos than that of Cairina moschata. Likewise, $\mathrm{Z}$ chromosome was subtelocentric in Anas platyrhynchos, while it was acrocentric in Cairina moschata (Islam et al., 2013). The W chromosome was small sized subacrocrocentric in Anas breeds while it was acrocentric in Cairina breeds. On the other hand, significant differences were found in the relative lengths of chromosome nos $(1,2,3,6,7$ and 8) across the two studied duck species (Anas platyrhynchos and Cairina moschata) whereas; lengths of chromosome nos 4, 5, 9, $\mathrm{Z}$ and W) were relatively the same in the two species (Ata et al., 2017).

Conventional banding techniques facilitate differentiation of bird chromosomes (Bitgood and Shoffner, 1990; Ata et al., 2005). One of the most commonly applied chromosome banding techniques is the RBG banding method. Another standard chromosome banding method is the CBG banding method (Wójcik and Smalec, 2007a and 2008a; Shahin et al., 2014 and Ata et al., 2019). Many Cytogenetic studies were targeted to develop a standard chromosome banding patterns for ducks 
and geese (Apitz et al., 1995; Denjean et al., 1997; Andraszek and Smalec, 2007; W'ojcik and Smalec, 2007a, b; W'ojcik and Smalec, 2008a, b; Shahin et al., 2014 and W'ojcik and Smalec, 2017). The only band pattern standard was for Gallus domesticus which approved by the International System for Standardized Avian Karyotypes (LadjaliMohammedi et al., 1999). G-band is a technique used in cytogenetics to produce a physical giemsa banding mapping of condensed chromosomes and identify the pair of each homologous chromosome by their characteristic band patterns. G bands are obtained as a result of initial trypsin digestion and then applying Giemsa dye - GTG pattern or Leishman dye - GTL pattern (Seabright, 1971 and 1973). As a result, cytogenetic analyses of bird chromosomes are conducted on the basis of partial ideograms predominantly including the first 8-9 pairs of the largest chromosomes (Schmid et al., 2000 and 2005).

Consequently, this work aimed at describing the karyotypes of three duck breeds (pekin, soudani and baladi) occurring in Egypt by means of conventional staining and G-banding technique.

\section{MATERIALS AND METHODS}

\subsection{MATERIALS}

The present work was carried out at the Department of Genetics, Faculty of Agriculture, Minia University on three different duck breeds (Pekin, Soudani and Baladi). The Ducks were obtained from El-Serw Waterfowls Research Station, Dimiata, Animal Product Research Institute, Agriculture Research Center, Ministry of Agricultural, Egypt. To describe the karyotype of the three duck breeds including conventional and G-banding patterns. Bone marrow cells were taken from 12 birds, 4 (one female and three males) from each breed.

\subsection{CONVENTIONAL KARYOTYPE ANALYSIS}

\subsubsection{CHROMOSOMAL PREPARATIONS}

The mitotic chromosome preparations were carried out according to the method of Yosida (1973), with the modifications of Ata et al. (2005). Birds were injected with $0.1 \mathrm{ml}$ of $0.02 \%$ colchicine intraperitoneally, $45 \mathrm{~min}$ later, the femurs and tibias were rapidly removed and the bone marrow was immediately flushed out with $0.56 \% \mathrm{KCl}$ in conical centrifuge tube. Cell suspension was incubated at 37 ${ }^{\circ} \mathrm{C}$ for $30 \mathrm{~min}$, and centrifuged at $5000 \mathrm{rpm}$ for 10 min. The supernatant was discarded and $5 \mathrm{ml}$ of cooled fresh prepared fixative solution (3 Methanol: 1 Acetic Acid) was added without disturbing the pellet, and incubated for $30 \mathrm{~min}$ at room temperature. Re-suspended the pellet and centrifuged is immediately done after washing by fixative. The supernatants were replaced with fresh fixative solution and re-centrifuged for three times. The white colored cell suspension was kept in the fixative solution and stored at $4{ }^{\circ} \mathrm{C}$. Small drops of cell suspension were put onto the dried slide surface using a Pasteur pipet and the cell spots were left to dry at room temperature. Air dried slides were stained with $4 \%$ Geimza dye solution for 5 min at room temperature, then washed with tape water

\subsubsection{KARYOTYPE ANALYSIS}

For conventional karyotype analysis, 30 good metaphase spreads from each bird (male and female) were scored and photographed using Olympus BX51 microscope with a C-4040 zoom digital camera. Eight pairs of macrochromosomes including sex chromosomes were counted and measured using Soft Imaging System (SIS) program (version 3.0) to estimate chromosome length; long (L) and short (S) arm lengths. The arm ratio (L / S) for each macrochromosome were calculated and nomenclature classific ation of centromere positions was done according to the method of (Levan et al., (1964).

To evaluate the significance of variation in chromosome parameters between the studied duck breeds, analysis of variance (ANOVA) and LSD values were statistically estimated using MSTAT program (Gomes and Gomes, 1984).

Karyotype ideogram was designed using softw are so called Karyotype that made by Altinordu et al. (2016). The primary function of this software is to allow efficient measurements of chromosomes and micro-photographic for karyotyping analysis. Karyotype software also has the potentiality for analyzing karyotype asymmetry indices such as Index of karyotype asymmetry (AsK) and inter chromosomal asymmetry index (A), which can recognize chromosome homology that based on chromosome length and arm ratio automatically or manually. The Karyotype measured metric s include chromosome length (CL), arm ratio (AR), centromeric index $(\mathrm{CI})$, relative length (RL) and karyotype formula where chromosomes were arranged according to their total length. Karyotype parameters in addition to karyotype asymmetry index (AsK) were estimated as prsented in Table (1). 
Table 1. Karyological parameters used to explore the karyotype of the three duck breeds

\begin{tabular}{lll}
\hline Karyological parameters & Abbreviation & Formula \\
\hline Short arm length & $\mathrm{S}$ & \\
Long arm length & $\mathrm{L}$ & \\
Chromosome length & $\mathrm{CL}$ & $\mathrm{L}+\mathrm{S}$ \\
Arm ratio & $\mathrm{AR}$ & $\mathrm{L} / \mathrm{S}$ \\
Index of karyotype asymmetry & AsK\% & Length of long arms in chromosome set / \\
Intra chromosomal asymmetry degree & AsD & Total chromosome length in set $\times 100$ \\
\hline
\end{tabular}

\subsection{G-BANDING PATTERNS OF DUCK BREEDS}

Giemsa banding method was applied to identify the pair of each homologous chromosome by their characteristic banding patterns. The method of Yosida and sagai (1972), with some modifications by Ata and Shahin (1999) and El-Ashmawy et al. (2000) was applied. Slides were incubated in $2 \mathrm{X}$ (sodium chloride and sodium citrate) for one hour at $60 \mathrm{C}^{\circ}$ and then washed by distilled water. the slides were treated with $0.25 \%$ trypsin solution for $5-7 \mathrm{sec}$ at $0 \mathrm{C}^{\circ}$, incubated in $70 \%$ ethanol for $1 \mathrm{~min}$ and then washed with distilled water and stained in Giemsa stain solution (1:24 buffer, PH 7.0) for 3-4 min at room temperature. The slides were then washed in a distilled water and air-dried. About 25 metaphase spreads form both males and females at each duck breed were examined. G-banding ideograms were constructed using Adobe Photoshop 7.0 program.

\section{RESULTS AND DISCUSSION}

\subsection{KARYOTYPE ANALYSIS}

In order to characterize the karyotype variation among the studied duck breeds (Pekin, Soudani and Baladi), the largest eight chromosomes (including $\mathrm{ZW}$ ) were identified as macrochromosomes. Table (2) showed the mean values of some karyological measurements such as lengths of long (L) and short (S) arms, arm ratio, and total chromosome length of these breeds. Several tables of ANOVA are not shown.

The remaining 32 pairs which appear as dots under light microscope were classified as microchromosomes at metaphase cells of the three studied breeds as shown in Fig. (1). In general, there were no significant differences in the total lengths $(5.652$, 6.454 and $6.744 \mu \mathrm{m}$ ) of the largest chromosome (pair no.1) between Balady, Pekin and Soudani duck breeds, respectively.

Table 2. Karyological parameters of macro-chromosomes ( 7 autosomes) and $\mathrm{ZW}$ sex chromosomes of the three duck breeds.

\begin{tabular}{|c|c|c|c|c|c|c|c|c|c|c|}
\hline \multirow{2}{*}{ Breeds } & \multirow{2}{*}{ Parameters } & \multicolumn{9}{|c|}{ chromosomes } \\
\hline & & 1 & 2 & 3 & 4 & 5 & 6 & 7 & $\mathbf{Z}$ & $\mathbf{w}$ \\
\hline \multirow{4}{*}{ Balady } & $\mathbf{L}$ & 3.878 & 3.098 & 2.388 & 1.990 & 1.680 & 1.406 & 1.268 & 1.702 & 0.898 \\
\hline & $\mathbf{S}$ & 1.804 & 1.722 & 1.144 & 1.078 & 0.846 & 0.690 & 0.838 & 0.492 & 0.338 \\
\hline & CL & 5.652 & 4.814 & 3.532 & 3.068 & 2.526 & 2.096 & 2.106 & 2.194 & 1.236 \\
\hline & $\mathbf{A R}$ & 2.220 & 1.856 & 2.344 & 2.030 & 2.032 & 2.102 & 1.558 & 3.874 & 3.008 \\
\hline \multirow{4}{*}{ Pekin } & $\mathbf{L}$ & 4.202 & 3.052 & 2.516 & 1.988 & 1.516 & 1.280 & 1.132 & 1.738 & 0.918 \\
\hline & $\mathbf{S}$ & 2.252 & 1.760 & 1.698 & 1.072 & 1.030 & 0.714 & 0.656 & 0.954 & 0.506 \\
\hline & CL & 6.454 & 4.812 & 4.214 & 2.920 & 2.546 & 2.030 & 1.788 & 2.692 & 1.424 \\
\hline & $\mathbf{A R}$ & 2.164 & 1.800 & 1.556 & 2.136 & 1.494 & 1.704 & 1.760 & 1.886 & 2.166 \\
\hline \multirow{4}{*}{ Soudani } & $\mathbf{L}$ & 4.762 & 3.550 & 2.934 & 2.248 & 1.754 & 1.448 & 1.146 & 1.922 & 0.916 \\
\hline & $\mathbf{S}$ & 1.982 & 1.820 & 1.410 & 1.116 & 0.894 & 0.850 & 0.668 & 0.640 & 0.394 \\
\hline & CL & 6.744 & 5.370 & 4.356 & 3.364 & 2.648 & 2.190 & 1.814 & 2.562 & 1.290 \\
\hline & $\mathbf{A R}$ & 2.460 & 2.190 & 2.368 & 2.152 & 2.122 & 2.296 & 1.984 & 3.604 & 2.422 \\
\hline LSDV & pha $=$ & 1.156 & 1.020 & 0.9932 & 0.7746 & 0.4368 & 0.4974 & 0.4638 & 1.040 & 0.6005 \\
\hline
\end{tabular}

$\mathrm{L}=$ Long arm $\quad \mathrm{S}=$ Short arm $\quad \mathrm{CL}=$ Total chromosome length $(\mathrm{L}+\mathrm{S}) \mathrm{AR}=$ Arm ratio $(\mathrm{L} / \mathrm{S})$ 
A

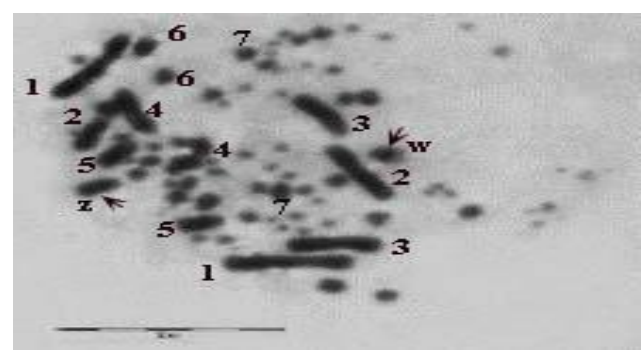

C

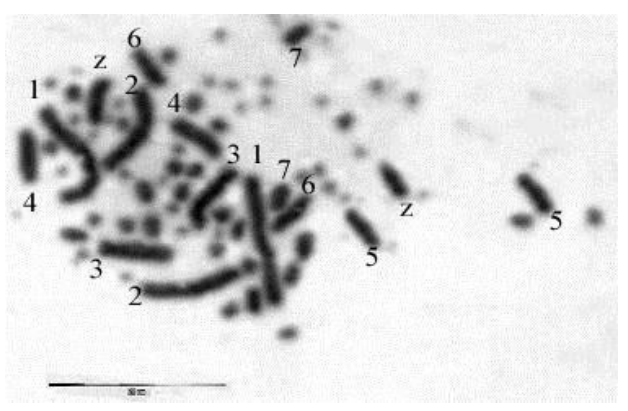

e

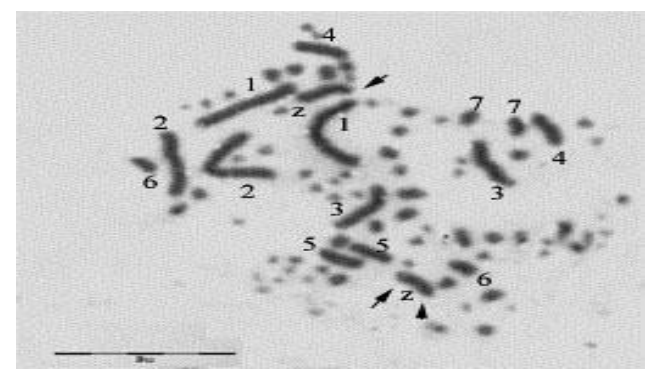

b

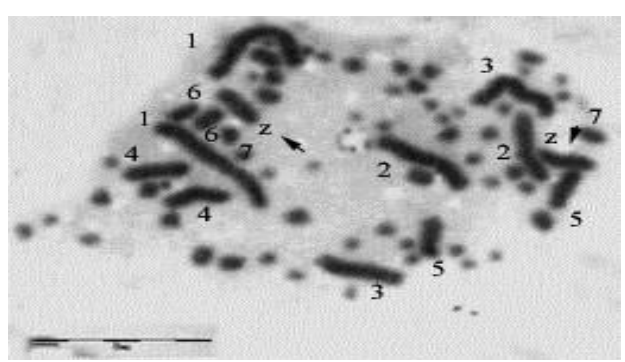

d

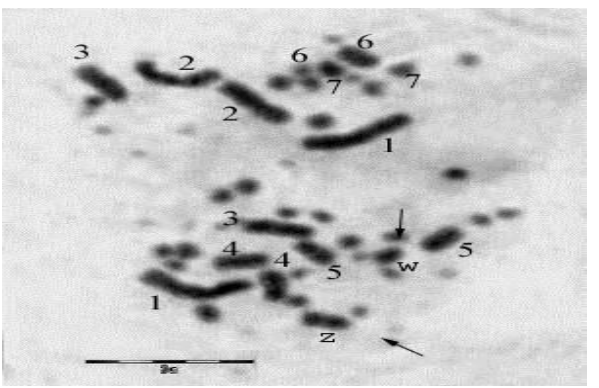

$\mathbf{F}$

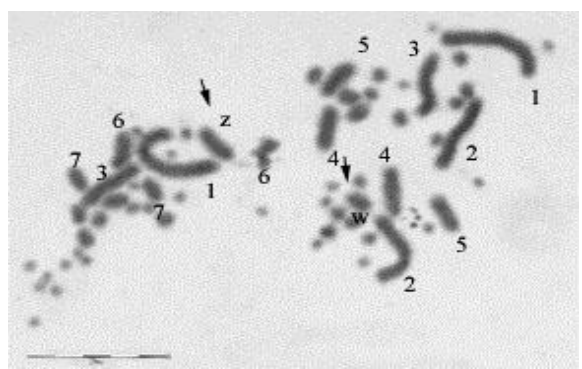

Fig 1. Metaphase spreads showing numbers of macro-chromosomes of both Males and Females of the three duck breeds: ( $a$ and b): male and female of Baladi duck breed, (c and d); male and female of pekin duck breed and (e and $f)$ : male and female of soudani duck breed. Arrows indicated to $Z$ and $W$. Scale bare $=20 \mu$

In the same manner, total lengths of pair nos. 2, 3, 4, 5, 6, 7, $\mathrm{z}$ and $\mathrm{w}$ were no significantly different between the studied duck breeds. In addition, the other karyotypic measurements such as lengths of the long and short arms and arm ratio of the analogous chromosomes in the studied three breeds showed no signific ant differences. However, data analysed by Karyotype software showed that the centromere positions of chromosome nos.3, 5, 6 were metacentrics in Pekin breed, while those of Baladi and Sudani were submetacentrics. Kayotype softw are analysis also showed that chromosome no.7 was metacentric and subtelocentric $\mathrm{Z}$ chromosome in Baladi, while those of Pekin and Sudani were submetacentrics (Fig. 2).
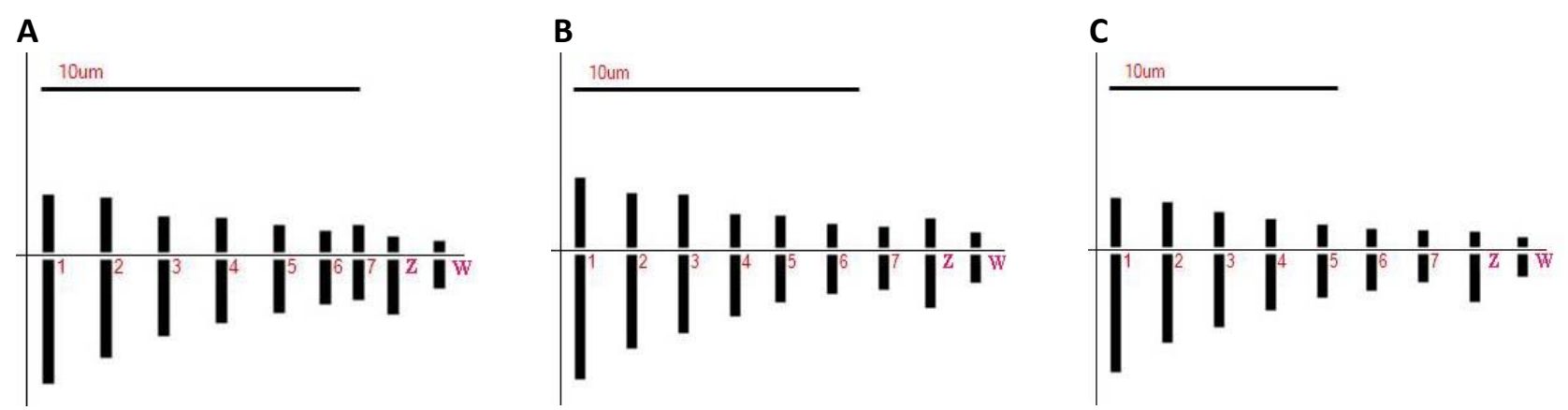

Fig 2. Karyograms showing the different categories of karyotypic formula in (A): in Baladi $(1 \mathrm{~m}+7 \mathrm{sm}+1 \mathrm{st}),(\mathrm{B})$ : in Pekin $(3 \mathrm{~m}+6 \mathrm{sm})$ and $(\mathrm{C})$ : in.Soudania $(9 \mathrm{sm})$, bar= 10 microns. 


\subsection{VARIATION OF KARYTYPIC FORMULA RESULTED AFTER DATA ANALYSIS WITH KARYOTYPE SOFT WARE}

The karyotypic formula and asymmetry at metaphase cells of the three duck breeds were obtained after data analysis using software program (Karyotype) as shown Table (3) and Plate (1). Three different categories of karyotypic formula $(1 m+7 s m+1 s t, 3 m+6 s m$ and $9 s m)$ were observed in Baladi, Pekin and Soudani breeds, respectively.
Values of karyotypic asymmetry (a ratio between the total lengths of long arms in haploid set and total lengths of all chromosomes of haploid number indicating dominancy of either meta-or submetacentric) ranged from $62.98 \%$ to $68.14 \%$ and were evidently different among the studied breeds (Table 3). Furthermore, data in Table (3) revealed that the intra chromosomal asymmetry degree (AsD) diverse among the three breeds (3C in Baladi; $1 \mathrm{C}$ in Pekin and $3 \mathrm{C}$ in Soudani).

Table 3. karyotype formula, karyotypic asymmetry (AsK) and karyotypic asymmetry (AsD) chromosomes of mean values three duck breeds (Baladi, Pekin and Soudani)

\begin{tabular}{llll}
\hline \multirow{2}{*}{ Parameters } & \multicolumn{3}{c}{ Duck breeds } \\
\cline { 2 - 4 } & Baladi & Pekin & Soudani \\
\hline AsK & $67.13 \%$ & $62.98 \%$ & $68.14 \%$ \\
${ }^{* *}$ AsD & $3 \mathrm{C}$ tend to submetacentric & $1 \mathrm{C}$ tend to subtelocentrics & $3 \mathrm{C}$ tend to submetacentric \\
Formula & $2 \mathrm{n}=1 \mathrm{x}=1 \mathrm{~m}+7 \mathrm{sm}+1 \mathrm{st}$ & $2 \mathrm{n}=1 \mathrm{x}=3 \mathrm{~m}+6 \mathrm{sm}$ & $2 \mathrm{n}=1 \mathrm{x}=9 \mathrm{sm}$ \\
\hline *AsK= Total length of $\mathrm{L}$ in a chromosome set $/$ Total length of a chromosome set, ** AsD= asymmetry degree
\end{tabular}

To study the karyotypic variation among the three duck breeds (Baladi, Pekin and Soudani) means of the chromosome criteria (short arm, long arm, total length, arm ratio) of cells obtained from three different duck breeds were analyzed using the software Karyotype Altınordu et al., (2016). Generally, almost all examined cells of the three studied breeds showed 7 macro-chromosome pairs and $\mathrm{ZZ}$ or $\mathrm{ZW}$ and about 66 dot or so called microchromosomes.

Duck species maintenance is currently a matter of serious concern due to the uncontrolled breeding, interbreeding, and hybridization of domesticated and natural populations of closely related species all over the world (Seo et al., 2016). Differences in chromosome morphology including chromosome length (CL), arm ratio (AR), centromeric index $(\mathrm{CI})$, relative length (RL) and karyotypic formulas between analogous chromosomes of the studied three duck breeds (Baladi, Pekin and Soudani) may due to occurring of structural aberrations such as centromeric reposition, translocations, inversions, deletions and/or duplications (Ata et al., 2005; Islam et al., 2014 and Shahin et al., 2014). There are also huge differences between the karyotype reported herein and that early suggested by W'ojcik and Smalec (2007b) and (2008b), particularly in Z and W chromosomes (Ata et al., 2017). Two possibilities for the process of chromosome rearrangements in the $\mathrm{Z}$ chromosomes were suggested, centromere moving that occurred in the ancestral acrocentric $\mathrm{Z}$ chromosome of Galloanserae or, a pericentric inversion that occurred in the ancestral acrocentric $\mathrm{Z}$ chromosome, followed by at least one large paracentric inversion (Ata et al., 2007 and 2019). Systems include ZW (female heterogamety) in which the sex-specific element $\mathrm{W}$ is a more or less degraded version of the $\mathrm{Z}$ and is shorter because of deletion or longer because of insertion and amplification have also been suggested (Ezaz et al., 2017 and Ata et al., 2019). It is well known that using different software programs for analyzing chromosome data may result in misleading and making false differences between obtained karyograms (Altinordu et al., 2016).

Indeed, the avian $\mathrm{Z}$ chromosome is highly conserved in size and morphology across all bird families, then comparative chromosome painting and sequence analysis showed high sequence homology across the most distantly related birds, and physical mapping revealed high levels of linkage homology (Nishida-Umehara et al., 2007; Shetty et al., 1999; Shibusaw a et al., 2004 and Zhou, 2004). There is no sex-specific SRY in birds and reptiles, but the DMRT1 gene, which is present on the $\mathrm{Z}$ but absent on $\mathrm{W}$, is considered a good candidate sex determining gene (Marshall Graves and Shetty, 2001).

\subsection{G-BANDING OF THREE DUCK BREEDS}

Table (4) showed the mean numbers and types of G-banding after trypsin treatment of metaphase cells of three studied breeds (Baladi, Pekin and Sudani). Banding patterns either on $p$ arm or on q of macro-chromosome pair no.1 in Sudani breed were clearly different from those found in Baladi and Pekin. Similarly, the other six large autosomes (somatic macro-chromosomes nos.2 to 7 ) showed variable banding numbers and patterns across the three studied duck breeds. 
Table 4. mean number and patterns of G-bands on chromosome arms of Baladi, Pekin and Sudani duck breeds

\begin{tabular}{|c|c|c|c|c|c|c|}
\hline \multirow{2}{*}{$\begin{array}{c}\text { chromosome } \\
\text { Pair no. }\end{array}$} & \multirow[b]{2}{*}{ Arm } & \multirow[b]{2}{*}{ breed } & \multicolumn{4}{|c|}{ Numbers and types of G-bands } \\
\hline & & & Faint and weak & Light and white & Dark and sharp & Total \\
\hline \multirow{8}{*}{1} & \multirow{4}{*}{$\mathbf{P}$} & Baladi & 2 & 5 & 3 & 10 \\
\hline & & Pekin & 2 & 1 & 2 & 4 \\
\hline & & Sudani & $\mathbf{0}$ & 3 & 2 & 5 \\
\hline & & Baladi & 2 & 7 & 5 & 14 \\
\hline & \multirow[t]{3}{*}{$\mathbf{Q}$} & Pekin & 2 & 7 & 5 & 14 \\
\hline & & Sudani & 1 & 5 & 4 & 10 \\
\hline & & Baladi & 2 & 4 & 3 & 9 \\
\hline & $\mathbf{P}$ & Pekin & 1 & 3 & 2 & 6 \\
\hline \multirow{6}{*}{2} & & Sudani & $\mathbf{0}$ & 3 & 2 & 5 \\
\hline & & Baladi & 1 & 4 & 4 & 9 \\
\hline & $\mathbf{Q}$ & Pekin & 1 & 4 & 2 & 7 \\
\hline & & Sudani & 1 & 2 & 1 & 4 \\
\hline & & Baladi & 0 & 4 & 3 & 7 \\
\hline & $\mathbf{P}$ & Pekin & 1 & 3 & 2 & 6 \\
\hline \multirow{6}{*}{3} & & Sudani & 1 & 1 & $\mathbf{0}$ & 2 \\
\hline & & Baladi & 1 & 3 & 2 & 6 \\
\hline & $\mathbf{Q}$ & Pekin & 1 & 5 & 3 & 9 \\
\hline & & Sudani & 0 & 2 & 1 & 3 \\
\hline & & Baladi & 1 & 1 & 2 & 4 \\
\hline & $\mathbf{P}$ & Pekin & 1 & 2 & 1 & 4 \\
\hline \multirow{6}{*}{4} & & Sudani & 0 & 2 & 1 & 3 \\
\hline & & Baladi & 1 & 3 & 2 & 6 \\
\hline & Q & Pekin & 1 & 5 & 4 & 10 \\
\hline & & Sudani & 1 & 2 & 1 & 4 \\
\hline & & Baladi & 1 & 3 & 2 & 6 \\
\hline & $\mathbf{P}$ & Pekin & 1 & 2 & 1 & 4 \\
\hline \multirow{6}{*}{5} & & Sudani & 0 & 3 & 2 & 5 \\
\hline & & Baladi & 2 & 4 & 3 & 9 \\
\hline & Q & Pekin & 1 & 1 & 0 & 2 \\
\hline & & Sudani & 0 & 3 & 2 & 5 \\
\hline & & Baladi & 0 & 2 & 1 & 3 \\
\hline & $\mathbf{P}$ & Pekin & 1 & 1 & 1 & 3 \\
\hline \multirow{6}{*}{6} & & Sudani & 0 & 2 & 1 & 3 \\
\hline & & Baladi & 1 & 3 & 1 & 4 \\
\hline & Q & Pekin & 1 & 2 & 1 & 4 \\
\hline & & Sudani & 0 & 3 & 2 & 5 \\
\hline & & Baladi & 1 & 1 & 0 & 2 \\
\hline & $\mathbf{P}$ & Pekin & 0 & 2 & 1 & 3 \\
\hline \multirow{6}{*}{7} & & Sudani & 0 & 2 & 1 & 3 \\
\hline & & Baladi & 0 & 2 & 1 & 3 \\
\hline & $\mathbf{Q}$ & Pekin & 0 & 2 & 1 & 3 \\
\hline & & Sudani & 1 & 2 & 1 & 4 \\
\hline & & Baladi & 0 & 2 & 1 & 3 \\
\hline & $\mathbf{P}$ & Pekin & 0 & 2 & 1 & 3 \\
\hline \multirow{6}{*}{$\mathbf{Z}$} & & Sudani & 0 & 2 & 1 & 3 \\
\hline & & Baladi & 0 & 3 & 2 & 5 \\
\hline & Q & Pekin & 0 & 3 & 2 & 5 \\
\hline & & Sudani & 1 & 2 & 1 & 4 \\
\hline & & Baladi & 1 & 1 & 0 & 2 \\
\hline & $\mathbf{P}$ & Pekin & 0 & 3 & 2 & 5 \\
\hline \multirow{4}{*}{$\mathbf{W}$} & & Sudani & 1 & 2 & 1 & 4 \\
\hline & & Baladi & 1 & 2 & 2 & 4 \\
\hline & Q & Pekin & 0 & 3 & 2 & 5 \\
\hline & & Sudani & 1 & 2 & 1 & 4 \\
\hline
\end{tabular}


Fig. (3) also showed the microphotography of G-banded metaphase chromosome in both males and females of the three studied duck breeds. The faint, weak and dark G-bands were mapped on the

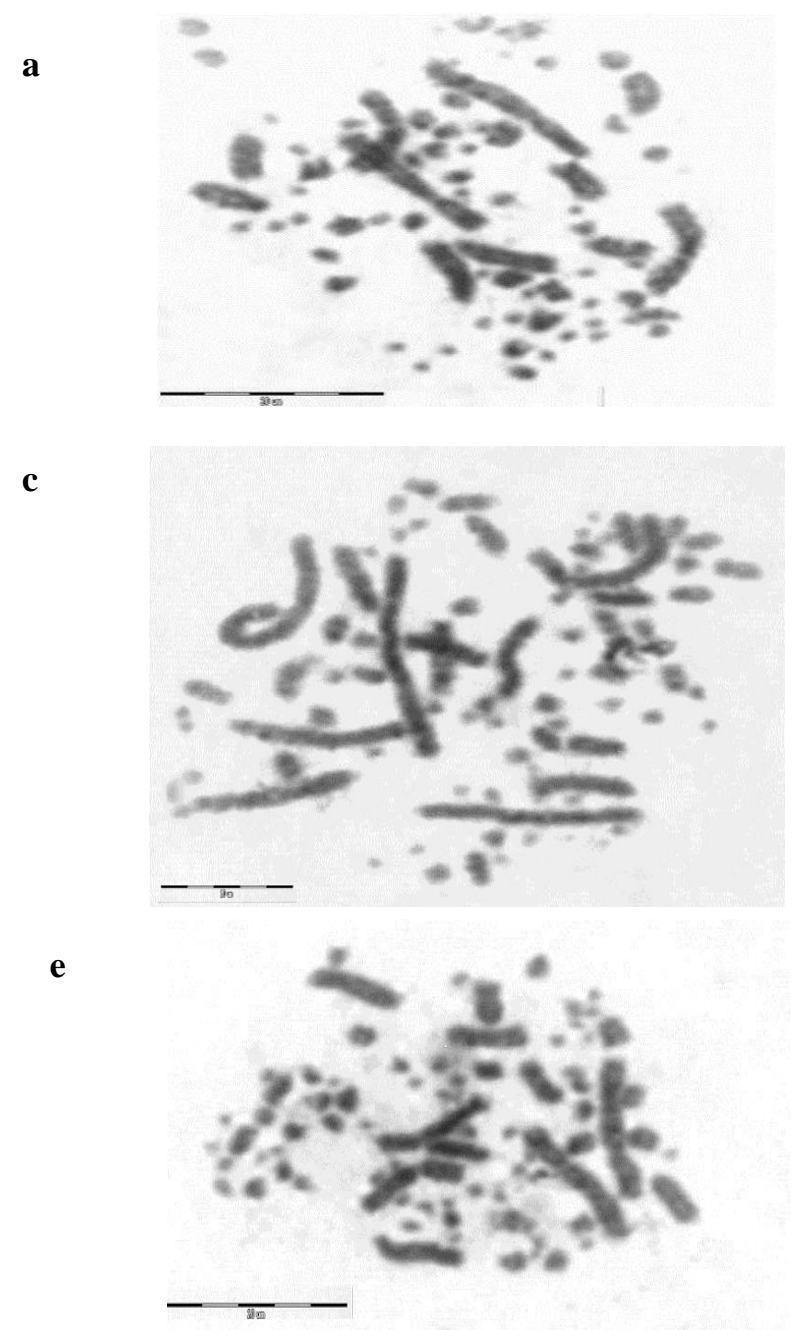

karyogram of those breeds (Fig. 4). The constructed physical G-banding maps have confirmed the variation in numbers and localizations of G-bands among the studied duck breeds.

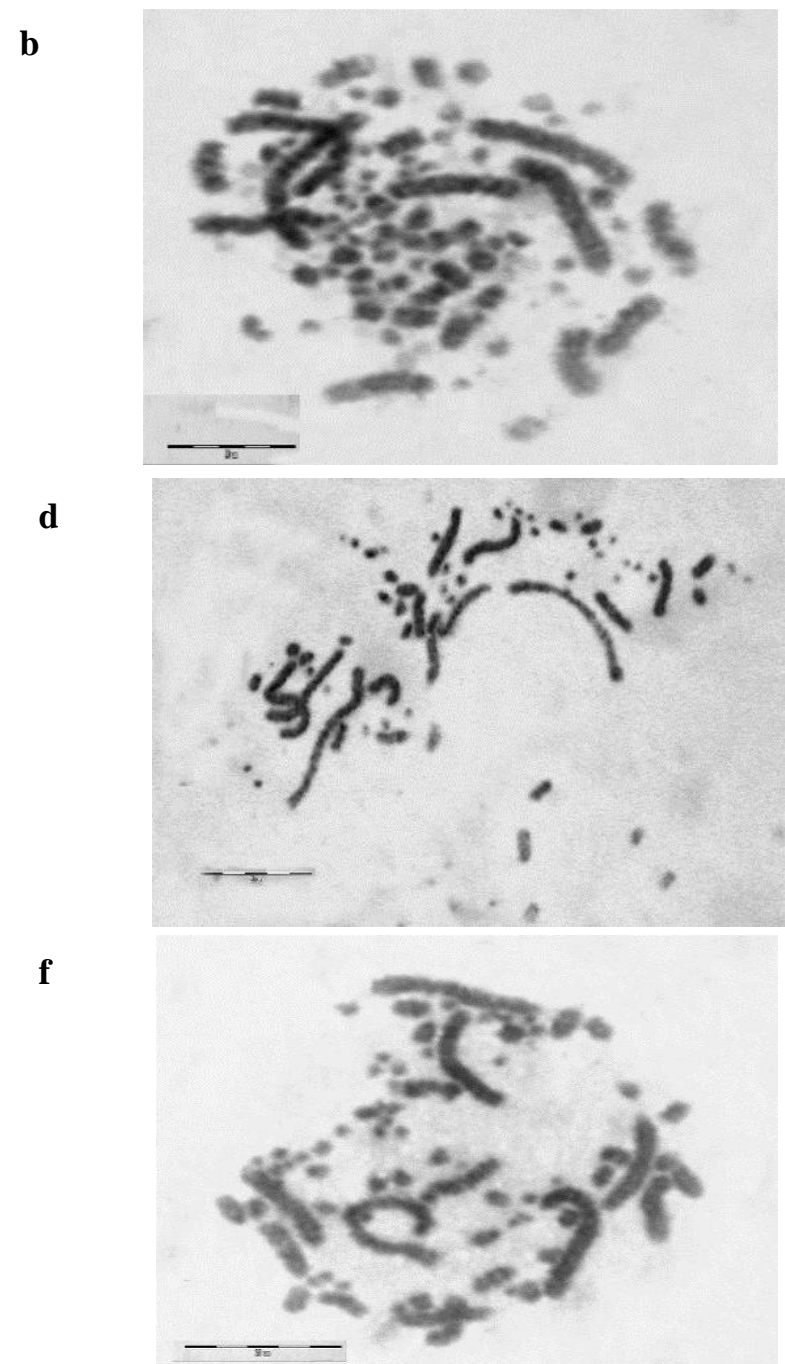

Fig 3. G-banding patterns of metaphase chromosomes in two cells of Baladi (a and b), Pekin (c and d) and Soudani (e and f) duck breeds. Scale bare $=20 \mu$

The differential banding technique applied to allow determination of G-banding pattern on the macro-chromosomes (including $\mathrm{Z}$ and $\mathrm{W}$ ) of the three studied duck breeds (Baladi, Pekin and Sudani). Data reported herein disagree with those of Apitz et al. (1995), W'ojcik and Smalec, (2007b and 2017) and Ata et al. (2017 and 2019). Making Gbanding karyotype in an individual or a species is fundamental for genome mapping attempt as both genetical and physical maps are made with respect to the chromosome position (Masabanda et al., 2004). It was recommended by Ladjali-Mohammedi et al. (1999) and Schmid et al. (2000) to apply general guidelines developed for chicken to other avian species. Analysis of the duck karyotype was done in a limited number of researches works. Two of them presented G-banding pattern for 5 (Apitz et al., 1995) and 12 chromosomes (Denjean et al., 1997) of two duck species (A. plathyrynchos and $C$. moschata). Both teams described the $\mathrm{Z}$ and $\mathrm{W}$ hetero-chromosomes. There were some divergences in the banding pattern of duck chromosomes proposed (No. 3 and 2) that could be attributed to a different contraction during the cell cycle.

The differences of G-banding patterns between of duck species were remarkably found in the 2nd and $\mathrm{Z}$ chromosomes (Apitz et al., 1995) or to the 3rd, 5th, 7th and $\mathrm{Z}$ chromosomes (Denjean et al., 1997). The ideogram of eight G-banded macrochromosomes and Z chromosome Denjean et al. (1997) cited in the First Report on Chicken Genes and Chromosomes (2000) differ from those presented in the original 
A

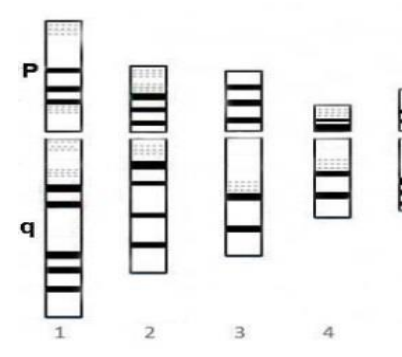

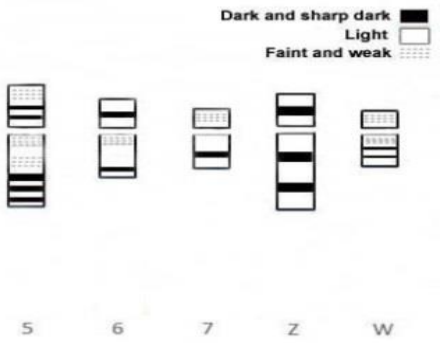

B

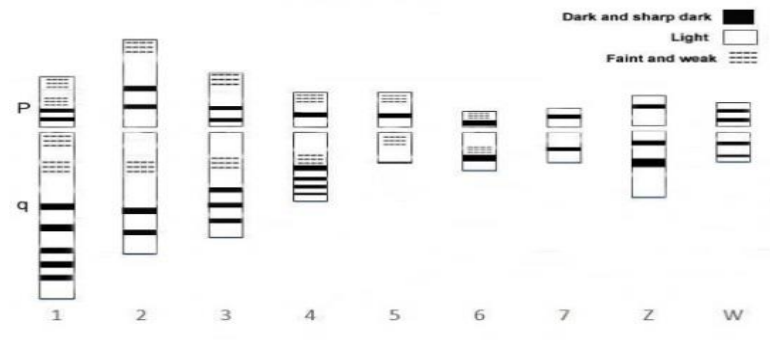

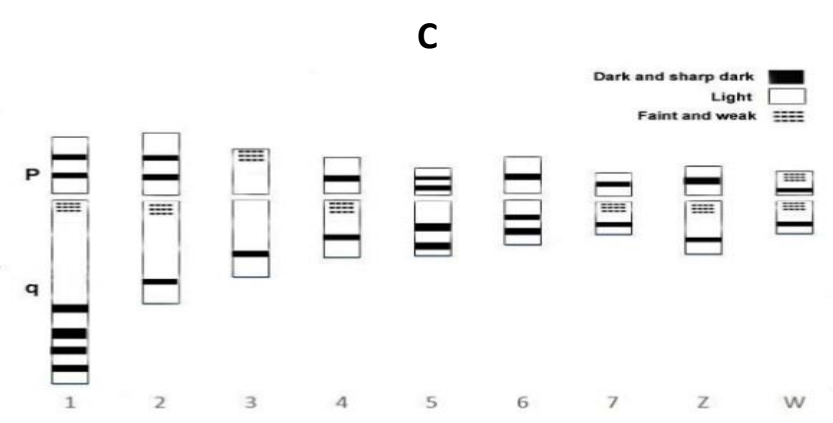

Fig 4. The physical G-banding maps of baladi (a), pekin (b) and soudani (c) duck breeds. Black indicates to the dark band, dots to the weak and faint and whit to the light bands

work in regard to the number of $\mathrm{G}$ positive bands (68 in the original paper vs 62 in the paper of Schmid et al. (2000). The karyotype comparison between duck species reflects differences of the 2nd, 3rd, 5th, 7th and $\mathrm{Z}$ chromosomes. Indeed, Apitz et al. (1995), Hailu et al. (1995) and Ducos et al. (1997) could determine differences in chromosome size between duck species. In conclusion, there is lack of comparable studies on $\mathrm{R}$ banding chromosomes in ducks.

\section{CONCLUSION}

This work aimed at describing the karyotypes of three duck breeds (pekin, soudani and baladi) occurring in Egypt by means of conventional staining and G-banding technique. Differences in chromosome morphology, G banding and karyotypic formulas between the studied three duck breeds were clearly observed. The application in the cytogenetic analysis of computer-generated chromosomal profiles that contain many bands makes it possible to determine a complete banded pattern even on short chromosomes individual of late metaphase. Duck breeds common in Egypt could be recognized from those present elsewhere, via the scattering and variability of banding patterns. Therefore, some molecular studies (under publication) will explain the genetic makeup of duck breeds occurring in Egypt.

\section{REFERENCES}

Altınordu F, Peruzzi L, Yan Y, He, X (2016). A tool for the analysis of chromosomes: KaryoType. Taxon, 1- 7.
Andraszek K, Smalec E, Wrzaszcz L (2007). Description ofGbands on the chromosomes of the European domestic goose (Anser anser). Arch. Geflügelk. 71: 272-277.

Apitz M, Wagner KU, Saar W (1995). Karyotype characteristics in domestic ducks and geese. Proceedings of 10th European Symposium on Waterflow 1, Halle, Germany, 465-472.

Ata AM, Shahin AAB (1999). Variation of G-band in the chromosomes of Allactaga tetradactyla, Jaculus jaculus and Jaculus orientalis (Rodentia, Dipodidae) common in Egypt. J. Union Arab Biol. Cairo. 11(A): 295-309.

Ata AM, Nassif FA, Abu Salha E, Fandy MW (2005). Cytogenetic studies on three species of domestic birds (Galliformes, Aves): I-Chromosome morphology and C-banding analysis. Minia Journal of Agriculture Research and Development 25: 977 1000.

Ata AM, Abu salha AE, Allam HZ, Fandy WA (2007). Cytogenetic studies on two species of domestic birds (Galliformes, aves): II-Meiotic behavior. African Crop Science Conference Proceedings. 8: 777-781.

Ata AM, Abu salha AE, Allam HZ, Fandy WA (2017). Karyological studies on some breeds of duck. Minia Journal of Agriculture Research and Development 37(1) 61-81.

Ata AM, Allam HZ, Abousalha AE, Fandy WM, Anwaar SM Abu Shnaf (2019). Constitutive Heterochromatin Pattern of Five Domestic Duck Breeds, (Aves: Anatidae) in Egypt. Egypt. Acad. J. Biolog. Sci., 11(2): 57- 69. 
Bitgood J, Shoffner RN (1990). Cytology and cytogenetics, In: Poultry breeding and genetics. Crawford, R.D. (ed), Elsevier Science Publishers, Amsterdam-Oxford-New York-Tokyo, 401-427.

Denjean B, Duclos A, Darre A, Pinton A, Seguela A, Berland $H$, Blanc MF, Fillon $V$ Darre $R$ (1997). Caryotypes des canards commun (Anas platyrhynchos), Barbarie (Cairina moschata) et de leur hybride. Revue. Méd. Vet. 148: 695-704.

Ducos A, Berland H, Pinton A, Seguela A, Blanc MF, Darr6 A, Darr6 R (1997). Les translocations r6ciproques chez le porc: 6tat des lieux et perspectives. In: 29èmes Journées de la Recherche Porcine en France, Paris, 4-6 f6vrier 1997, Institut technique du porc, Paris, 29: 375-382.

El-Ashmawy SH, Allam H Z, Osman SAM (2000). Giemsa Banding Patterns of Domestic Sheep introduced to Egypt From Syria (Asia), Sudan (Africa) and Cyprus (Europe). Proceedings of the 2nd Arab Conference Genetic Science and Biotechnology, El-Minia, Egypt, 23-26 October. 281-300

Ezaz T, Srikulnath K, Graves JA (2017). Origin of Amniote Sex Chromosomes: An Ancestral SuperSex Chromosome, orCommon Requirements? Journal of Heredity 108: 94-105.

FAO (2019). FAO statistical yearbook: Africa Food and Agriculture. FAO [cited 2019 May 2]; Availablefrom: $\quad$ http://www.fao.org/poultryproduction-products/products- processing/en/.

Griffin DK, Robertson LBW, Tempest HG, Skinner BM (2007). The evolution of the avian genome as revealed by comparative molecular cytogenetics. Cytogenetic and Genome Research 117: 64-77

Gomes KA, Gomes AA (1984). Statistical procedures of agricultural research. John Willy\& Sons, New York.

Hailu A, Balkew M, Berhe N, Meredith SEO, Gemetchu T (1995). Is Phle-botomus (Larroussius) orientalis a vector of visceral leishmaniasis in SouthwestEthiopia? Acta Trop. 60: 15-20.

Islam FB, Ishishita S, Uno Y, Mollah MR, Srikulnath K, Matsuda Y (2013). Male Hybrid Sterility in the Mule Duck is Associated with Meiotic Arrest in Primary Spermatocytes. Journal of Poultry Science 50: 311-320.

Islam FB, Uno Y, Nunome M, Nishimura $O$, Tarui H, Agata K, Matsuda Y (2014). Comparis on of the Chromosome Structures between the Chicken and Three Anserid Species, the Domestic Duck (Anas platyrhynchos), Muscovy Duck (Cairina moschata), and Chinese Goose (Anser cygnoides), and the Delineation of their Karyotype Evolution by Comparative Chromosome Mapping. Journal of Poultry Science 51: 1-13.
Ladjali-Mohammedi K, Botgood JJ, TixierBoichard M, Ponce De Leon FA (1999). International System for Standardized Avian Karyotypes (ISSAK): Standardized Banded Karyotypes of the Domestic Fowl (Gallus domesticus). Cytogenetics and Cell Genetics 86: 271276.

Levan A, Fredga K, Sandberg AA (1964). Nomenclature for centromeric position on chromosomes. Hereditas 52: 201- 220.

Livezey BC (1997). A phylogenetic analysis of basal Anseriformes, the fossil Presbyornis, and the interordinal relationships of waterfowl. Zoological Journal of the Linnean Society 121(4): 361-428.

Marshall Graves JA, Shetty S (2001). Sex from W to Z: evolution of vertebrate sexchromosomes and sexdetermining genes. J Exp Zool 290: 449-62.

Masabanda JS, Burt DW, O'brien PC, Vignal A, Fillon V, Walsh PS, Cox H, Tempest HG, Smith J, Habermann F, Schmid M, Matsuda Y, Fergusonsmith MA, Crooijmans RP, Groenen MA, Griffin DK (2004). Molecular Cytogenetic Definition of the Chicken Genome: The First Complete Avian Karyotype. Genetics 166: 13671373.

Nishida-Umehara C, Tsuda Y, Ishijima J, Ando J, Fujiwara A, Matsuda Y, Griffin DK (2007). The molecular basis of chromosome orthologies and sex chromosomal differentiation inpalaeognathous birds. Chromosome Research 15: 721-34.

Schmid M, Nanda I, Guttenbach M, Steinlein C, Hoehn H, Schartl M, Haaf T, Weigend S, Fries R, Buerstedde JM, Wimmers K, Burt DW, Smith J, A'hara S, Law A, Griffin DK, Bumstead N, Kaufman J, Thomson PA, Burke T, Groenen MAM, Crooijmans RPMA, Vignal A, Fillon V, Morisson M, Pitel F, Tixier-Boichard M, LadjaliMohammedi K, Hillel J, Maki-Tanila A, Cheng HH, Delany ME, Burnside J, Mizuno S (2000). First Report on Chicken Genes and Chromosomes 2000. Cytogenetics and Cell Genetics 90: 69-218.

Schmid M, Nanda I, Hoehn H, Schartl M, Haaf T, Buerstedde JM, Arakawa H, Caldwell RB, Weigend S, Burt DW, Smith J, Griffin DK, Masabanda JS, Groenen MA, Crooijmans M, Vignal RPM, Fillon AA, Morisson V, Pitel F, Vignoles A, Garrigues J, Gellin AV, Rodionov SA, Galkina NA, Lukina G, Ben-Ari S, Blum J, Hillel T, Twito U, Lavi L, David MW, Feldman ME, Delany CA, Conley VM, Fowler SB, Hedges R, Godbout S, Katyal C, Smith Q, Hudson A, Mizuno $S$ (2005). Second Report on Chicken Genes and Chromosomes 2005. Cytogenetic and Genome Research 109: 415-479.

Seabright M(1971). A Rapid Banding Technique for Human Chromosomes. Lancet 2: 971-972. 
Seabright M (1973). Improvement of Trypsin Method for Banding Chromosomes. Lancet 1: 12491250.

Seo D, Bhuiyan MS, Sultana H, Heo JM, Lee JH (2016). Genetic Diversity Analysis of South and East Asian Duck Populations Using Highly Polymorphic Microsatellite Markers. Asian-Australasian Journal of Animal Sciences 29: 471-478.

Shahin AA, Ata AM, Abu Shnaf SA (2014). Karyotype and C-banding pattern of the domestic geese Anser anser populations (Aves: Anatidae) in Egypt. Folia Boil. (KraKow), 62: 47-56.

Shetty S, Griffin DK, Graves JA (1999). Comparative painting reveals strong chromosome homology over 80 million years of bird evolution. Chromosome Research 7:289-95.

Shibusawa M, Nishibori M, Nishida-Umehara C, Tsudzuki M, Masabanda J, Griffin DK, Matsuda Y (2004). Karyotypic evolution in the Galliformes: an examination of the process of karyotypic evolution by comparison of the molecular cytogenetic findings with the molecular phylogeny. Cytogenetics and Genome Research 106: 111-9.

Sokolowskaja JJ (1935). Experiments on hybridisation of birds. I. Sex-linked characters in hybrids of Cairina moschata and Anus platyrhyncha. Zeits. Zool. 13: 481-496.

W'ojcik E, Smalec E (2007a). Description of the Anser anser goose karyotype. Folia Biol. (Kraków) 55: 35-40.
W'ojcik E, Smalec E (2007b). Description of the mallard duck (Anas platyrhynchos) karyotype. Folia Boil. (KraKow), 55: 115-20.

W'ojcik E, Smalec E (2008a). Description of the Anser cygnoides goose karyotype. Folia Biol. (Kraków) 56: 37-42.

W'ojcik E, Smalec E (2008b). The karyotype of domestic waterfowl: Ducks - RBG chromosome pattern. Arch Geflügelk 2008; 72: 207-212.

W'ojcik E, Smalec E (2017). Constitutive heterochromatin in chromosomes of duck hybrids and goose hybrids. Poultry Science, 96:18-26.

Yamashina Y (1941). Studies on sterility in hybrid birds. III. Cytological investigations of the intergeneric hybrid of the Muscovy duck (Cairina moschata) and the domestic duck (Anas platyrhyncha var. domestica). Jap. Jour. Genet 17: 207-228.

Yamashina Y (1942). A revised study of the chromosomes of the Muscovy duck, the domestic duck, and their hybrid. Cytologia 12:163-169.

Yosida TH (1973). Evolution of karyotype and differenation in 13 Rattus species. Chromosoma 40: 285-297.

Yosida TH, Sagai T (1972). Banding pattern analysis of polymorphic karyotype in the black rat by a new differential staining technique. Chromosome Bul. 37: 287-294.

Zhou $\mathbf{Z}$ (2004). The origin and early evolution of birds: discoveries, disputes, and perspectives from fossil evidence. Naturw issenschaften 91: 455-71. الملخص العزبى

\section{الإختلافات فى الطرز المجموعى الكروموسومى العادى والمجهز بالثرائط ج بين ثلاثة انواع من البط}

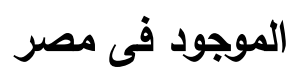

$$
\text { عبد التواب محمد عطا، سبا عبد المقصود عثمان، جيهان محمد انور، احمد على عبد الله }
$$

فى هذه الدراسة تم توضيح التباين الكروموسومى وعمل تحليل مقارن للطرز المجموعى الكروموسومى العادى والأخر المعد بشرائط من الطراز

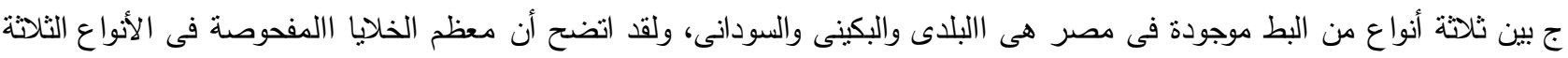

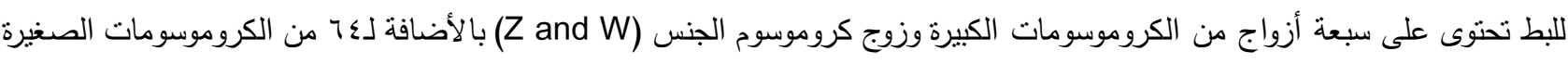

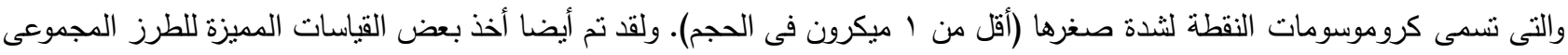

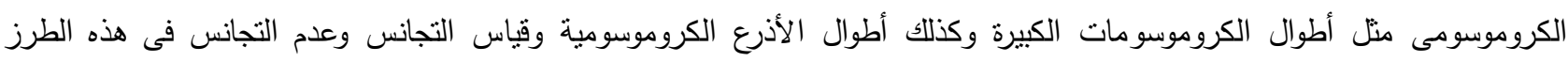

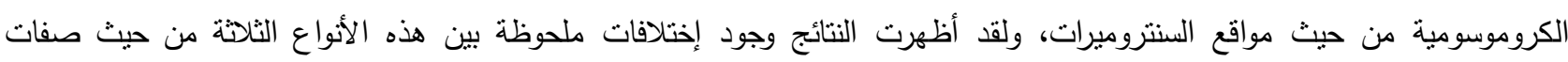

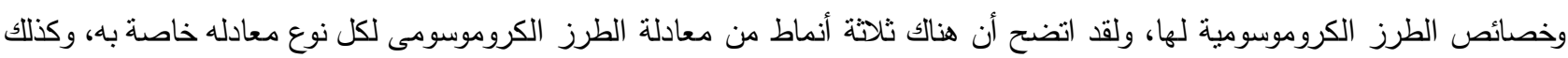

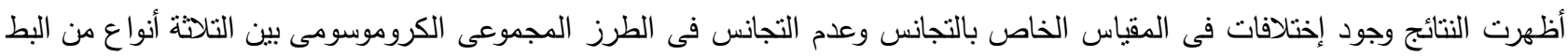

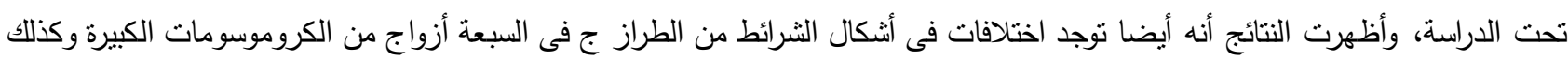

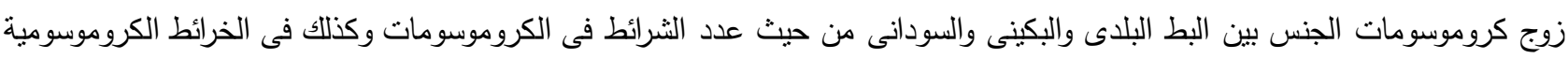
المجزة من هذه الثرائط. 